\title{
Design and Performance of Chromium Mist Generator
}

\author{
Aram Tirgar, ${ }^{a}$ Farideh Golbabaei, ${ }^{* a}$ Keramat Nourijelyani, ${ }^{b}$ Seyed Jamaleddin Shahtaheri, ${ }^{a}$ \\ Mohammad Reza Ganjali ${ }^{c}$ and Javad Hamedi ${ }^{d}$
}

${ }^{a}$ Department of Occupational Health and ${ }^{b}$ Department of Epidemiology and Biostatistics, School of Public Health and Institute of Public Health Research, Tehran University of Medical Sciences, P.O.Box 14155-6446 Tehran, Iran

${ }^{c}$ Department of Chemistry and ${ }^{d}$ Department of Biology, Faculty of Science, University of Tehran, Tehran, Iran

O gerador de névoa crômica homogênea é uma ferramenta essencial para pesquisas e avaliações científicas, sobre a poluição do ar e seus sistemas de controle. O objetivo desta pesquisa foi projetar e construir um gerador de névoa de cromo e estudar alguns fatores, como altura de amostragem e distâncias entre amostras, em amostragens lado a lado, com o método de amostragem de névoa crômica. O gerador de névoa foi construído, utilizando-se um recipiente de galvanoplastia em cromo, em escala piloto. As concentrações de $\mathrm{CrO}_{3}$ e ácido sulfúrico para solução de galvanização foram $125 \mathrm{~g} \mathrm{~L}^{-1}$ e $1,25 \mathrm{~g} \mathrm{~L}^{-1}$, respectivamente. Para criar locais de amostragem de ar permanentes, uma câmara cilíndrica Plexiglas ( $75 \mathrm{~cm}$ de altura, $55 \mathrm{~cm}$ i.d.), foi instalada na parte superior do recipiente. Sessenta furos foram feitos na câmara, distribuídos em três fileiras $(20 \mathrm{em}$ cada fileira). As distâncias entre fileiras e furos foram de $15 \mathrm{~cm} \mathrm{e} \mathrm{7,5} \mathrm{cm,} \mathrm{respectivamente.}$ Homogeneidade e efetividade foram estudados pelo método amostragens lado a lado. Assim, 48 agrupamentos de amostras foram coletados em filtros de cloreto de poli vinil (PVC) alojados em cartuhos. Os cartuhos foram localizados/conectados, a 35, 50 e $65 \mathrm{~cm}$ acima da superfície da solução, com $<7.5$ e/ou $7.5-15 \mathrm{~cm}$ de distância entre os topos. Todas as amostras foram analisadas de acordo com o método NIOSH 7600. Com base nas análises de variações (ANOVA), não foram observadas diferenças significantes entre os diferentes locais de lado a lado $(\mathrm{P}=0,82)$. Também, não houve diferença significante entre as diferentes alturas de amostragens e as distânciais de amostras ( $\mathrm{P}=0,86$ para ambas). Entretanto, houve notáveis diferenças entre a média de coeficiente de variação $(\mathrm{CV})$ em várias alturas e distâncias. Chegamos a conclusão, que a maior homogeneidade da névoa crômica poderia ser obtida na altura de $50 \mathrm{~cm}$ da superfície da solução do recipiente de galvanização, e distância de amostragens menor do que $7,5 \mathrm{~cm}$.

Chromium mist generator is an essential tool for conducting researches and making sciencebased recommendations to evaluate air pollution and its control systems. The purpose of this research was to design and construct a homogenous chromium mist generator and the study of some effective factors including sampling height and distances between samplers in side-by-side sampling on chromium mist sampling method. A mist generator was constructed, using a chromium electroplating bath in pilot scale. Concentration of $\mathrm{CrO}_{3}$ and sulfuric acid in plating solution was $125 \mathrm{~g} \mathrm{~L}^{-1}$ and $1.25 \mathrm{~g} \mathrm{~L}^{-1}$, respectively. In order to create permanent air sampling locations, a Plexiglas cylindrical chamber $(75 \mathrm{~cm}$ height, $55 \mathrm{~cm}$ i.d) was installed the bath overhead. Sixty holes were produced on the chamber in 3 rows (each 20). The distance between rows and holes was 15 and $7.5 \mathrm{~cm}$, respectively. Homogeneity and effective factors were studied via side-by-side air sampling method. So, 48 clusters of samples were collected on polyvinyl chloride (PVC) filters housed in sampling cassettes. Cassettes were located in 35, 50, and $65 \mathrm{~cm}$ above the solution surface with less than 7.5 and/or 7.5-15 cm distance between heads. All samples were analyzed according to the NIOSH method 7600. According to the ANOVA test, no significant differences were observed between different sampling locations in side-by-side sampling $(\mathrm{P}=0.82)$ and between sampling heights and different samplers distances ( $\mathrm{P}=0.86$ and 0.86 , respectively). However, there were notable differences between means of coefficient of variations $(\mathrm{CV})$ in various heights and distances. It is concluded that the most chromium mist homogeneity could be obtained at height $50 \mathrm{~cm}$ from the bath solution surface and samplers distance of $<7.5 \mathrm{~cm}$.

Keywords: mist generator, hexavalent chromium, side-by-side sampling, sampling height, samplers distance

\footnotetext{
* e-mail: gol128@sphtums.com
} 


\section{Introduction}

Hexavalent chromium $\left(\mathrm{Cr}^{6+}\right)$ is coming under increasing concern due to both environmental and worker health as well as safety issues. It is known as a carcinogenic compound, ${ }^{1-4}$ causing a wide array of medical problems especially in the nasal passages, ${ }^{5,6}$ contact dermatitis, ${ }^{7}$ respiratory tract irritation, ${ }^{8}$ occupational asthma, ${ }^{9}$ and kidney damage. ${ }^{10}$ Since occupational exposure to $\mathrm{Cr}^{6+}$ mostly occurs through respiratory tract, precise determination of $\mathrm{Cr}^{6+}$ in the air is vital necessity for assessment and control of air pollution. For this reason, there are varieties of analytical standard methods developed in different studies. ${ }^{11-15}$ These methods describe the sample collection and analysis of airborne $\mathrm{Cr}^{6+}$ used by industrial hygienists experienced in monitoring for exposures. Some of the above mentioned methods are: OSHA ID-215, ${ }^{12}$ NIOSH 7600, and NIOSH modified method 7605. ${ }^{13,14}$ Some efforts have been also directed toward the development of field-portable methods for on site measurement of $\mathrm{Cr}^{6+}$, which are often desired for quick decision making regarding workers protection, engineering control, etc. ${ }^{15}$

Recent changes to the EPA Clean Air Act have reduced the allowable $\mathrm{Cr}^{6+}$ levels in stack emissions from plating plants. Regarding the EPA's Metals Products and Machinery (MP\&M) guidelines proposed under the Clean Water Act, chrome-contaminated waste discharges will be severely curtailed. Based on concerns over worker health and safety, more stringent regulations on the permissible exposure limit (PEL) in the workplace are being considered by OSHA. ${ }^{16}$ Moreover, lack of a certain method to measure airborne $\mathrm{Cr}^{6+}$ concentration, ${ }^{11-15}$ possibility of effectiveness of some factors on $\mathrm{Cr}^{6+}$ determination, ${ }^{17}$ and also high number of exposed workers are all the main reasons, ${ }^{18}$ indicating that $\mathrm{Cr}^{6+}$ measurement needs more researches. Producing an atmosphere of known concentration of air contaminant is the primary step for facilitating above mentioned research. There are several mechanisms for producing $\mathrm{Cr}^{6+}$ mist. Kuo and Wang have constructed an experimental generation system, in which, generation of $\mathrm{Cr}^{6+}$ mist was performed on the basis of flowing the air through the $\mathrm{CrO}_{3}$ solution bath. ${ }^{19-21}$ Because the usage of electroplating process is so diverse that no single technology or material will be able to replace it, this would be the main source of the $\mathrm{Cr}^{6+}$ emission in the environment as well as the workplace. So, in the present study, a chromium electroplating bath was simulated to generate $\mathrm{Cr}^{6+}$ in accordance with real industrial sources.
The purpose of this study was to design and construct a chromium mist generator with ability of producing homogenous mist. By using this generator, assessment of samplers, filters, different sample preparation and analyzing methods could be possible. Also different effective factors on $\mathrm{Cr}^{6+}$ measurement in air and evaluation of control methods can be performed.

\section{Experimental}

\section{Mist generation}

It is indicated that, the generation of pure $\mathrm{Cr}^{6+}$ mist could be done in chromium electroplating process. ${ }^{21}$ Hence, hard chromium electroplating process was considered as the selected mechanism of $\mathrm{Cr}^{6+}$ mist generation.

\section{Mist generation mechanism}

The chromium electroplating process has a very low current efficiency in which about $80-90 \%$ of the applied current is being used to dissociate electrolyte and release gasses..$^{20}$ As the predominant constituent in the chromium electroplating bath is $\mathrm{CrO}_{3}$ (approximately 99\%), therefore, the gas bubbles are released at the cathode (hydrogen) and anode (oxygen) entrain chromic acid, causing almost a pure cloud of $\mathrm{Cr}^{6+}$ mist which can be released to the workplace and to ambient air (Figure 1). ${ }^{21}$

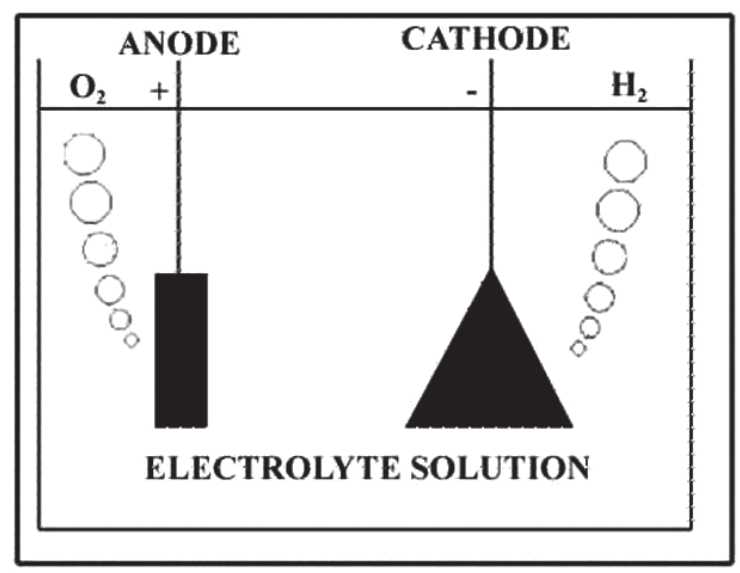

Figure 1. Release of hydrogen and oxygen gas bubbles at the electroplating solution surface.

\section{Mist generator specifications}

The bath was made of plastic drum $(120 \mathrm{~cm}$ height, $55 \mathrm{~cm}$ i.d.), containing electrolyte solution (Figure 2).

Since previous studies showed that, the size distribution of chromium mist depended on the 


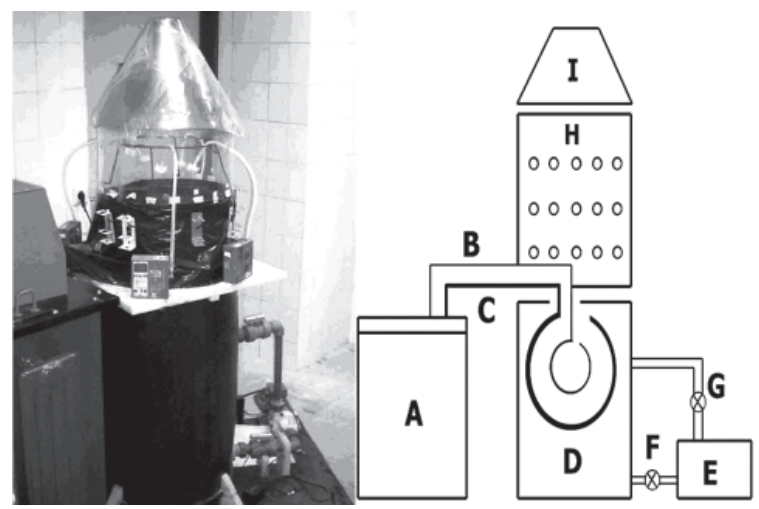

Figure 2. Set up of the mist generation device. A: rectifier, B: cathode, C: anode, D: electroplating bath, E: anti acid pump, F and G: valves, $\mathrm{H}$ : plexiglas case I: Hood.

electrolyte concentration, ${ }^{22}$ chromic acid solution with the concentration of $125 \mathrm{~g} \mathrm{~L}^{-1}$ was used as the electrolyte concentration level employed in practical applications. ${ }^{23}$ In order to have maximum uniformity to hydrogen and oxygen bubbles bursting on surface of electrolyte solution, anode and cathode were shaped in a circular form. To maintain a certain limited temperature range in the bath, an anti-acid pump was used. The electrolyte was then circulated for preventing to enhance its temperature. ${ }^{19}$

In order to create permanent sampling locations, a transparent insulated Plexiglas cylindrical chamber $(75$ $\mathrm{cm}$ height, $55 \mathrm{~cm}$ i.d.) was made and installed as the bath overhead (Figure 3, and H in Figure 2). Sixty holes were made on the chamber in 3 rows (each 20). The distance between rows and holes were $15 \mathrm{~cm}$ and $7.5 \mathrm{~cm}$, respectively. The sampling heads fixations were provided using a metal ring (Figure 3).

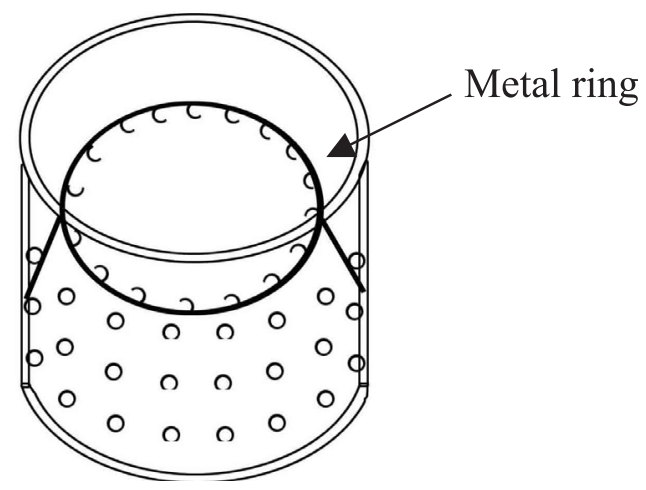

Figure 3. Plexiglas cylindrical chamber as an overhead of electroplating bath.

To prevent cross air flow disturbance on mist sampling, the electroplating assembly was located in an enclosed room with a current calm air.
Collection of samples

Regarding to the role of sampling height and samplers distances in side-by-side sampling on precise concentration measurement, the samples were collected at different heights $(35,50$, and $65 \mathrm{~cm}$ above the solution surface) and distances (<7.5 and 7.5-15 cm).

The filter cassette was positioned above the solution surface and the inlet of filter cassette faced downward at an angle of approximately $45^{\circ}$ normal to the solution surface. Simultaneous samples were taken, using $37 \mathrm{~mm}$ polystyrene closed-face filter cassettes. The samplers were located side-by-side at four sampling locations, chosen randomly. Each filter cassette containing a $5.0 \mu \mathrm{m}$ pore size PVC membrane filter (MSA, Pittsburgh, USA) connected to a personal sampling pump (model 224PCXR3; SKC, Blandford forum, UK). The sampling pumps were calibrated for the air flow rate of $2 \pm 0.1 \mathrm{~L}$ $\mathrm{min}^{-1}$. Sampling durations were kept between 10-190 min to maintain the filter permissible load. Electrolyte temperature was measured at the beginning and the end of each run $\left(18.3 \pm 1.6^{\circ} \mathrm{C}\right.$ and $18.5 \pm 1.6^{\circ} \mathrm{C}$, respectively).

Using NIOSH Method, ${ }^{13}$ each sampled PVC filter was extracted by 6-7 milliliter of $0.25 \mathrm{~mol} \mathrm{~L}^{-1} \mathrm{H}_{2} \mathrm{SO}_{4}$ for 5 to $10 \mathrm{~min}$, and then, $0.5 \mathrm{~mL}$ of 1,5-diphenylcarbazide solution was added to the extracted solution. The total volume of solution was brought to $25 \mathrm{~mL}$ with $0.25 \mathrm{~mol} \mathrm{~L}^{-1} \mathrm{H}_{2} \mathrm{SO}_{4}$. The absorbance of the color complex was measured at $540 \mathrm{~nm}$ by ultraviolet-visible (UV-Vis) spectrophotometer (Model DU640; Beckman, Fullerton, USA). The calibration curve was established with seven standard solutions at concentrations of 0.04 , $0.08,0.12,0.16,0.2,0.24$, and $0.28 \mu \mathrm{g} \mathrm{mL}^{-1}$ of $\mathrm{Cr}^{6+}$. A calibration curve revealed a correlation coefficient of 0.998 . By using calibration curve plot, $\mathrm{Cr}^{6+}$ concentration was determined.

Recovery efficiency (R.E) of chromium extraction from PVC filter was obtained experimentally. For this purpose, a known amount of potassium dichromate solution was added to the PVC filter and its recovery was determined for concentration for 1, 3, 5, $7 \mu \mathrm{g}$ per $25 \mathrm{~mL}$ after approximately $10 \mathrm{~min}$. R.E was calculated equal to $96 \pm 12.6 \%$.

\section{Results and Discussion}

This project was carried out in order to design and construct a $\mathrm{Cr}^{6+}$ mist generator to generate homogenous chromium mist. By means of this generator, conducting researches including assessment of samplers, filters, different sampling, and analyzing methods could be 
possible. Also, different factors on $\mathrm{Cr}^{6+}$ concentration measurement in air and evaluation of control methods can be performed.

According to the current method in evaluation of hexavalent chromium, precaution should be taken be considered that, total aerosol loading on the $37 \mathrm{~mm}$ diameter PVC filter not to exceed $1 \mathrm{mg}$. So, the loaded mass was calculated, using $\mathrm{Cr}^{6+}$ concentration $\left(\mathrm{mg} \mathrm{m}^{-3}\right)$ and sampled air volume $\left(\mathrm{m}^{3}\right)$. Results of chromium concentrations in different sampling locations are shown in Table 1. As the results show, a wide variety of $\mathrm{Cr}^{6+}$ concentrations ranging from 4.3 to $5000 \mu \mathrm{g} \mathrm{m}^{-3}$ with mass loading ranging from 0.9 to $480 \mu \mathrm{g}$ per filter were obtained.

The measured chromium concentrations were all greater than the OSHA proposed PEL ( $8 \mathrm{~h}$ time-weighted average) of $1 \mu \mathrm{g} \mathrm{m}^{-3}$, with $92.3 \%$ of the values exceeding the OSHA- PEL ceiling $\left(52 \mu \mathrm{g} \mathrm{m}^{-3}\right) .{ }^{16}$ Since chromium concentrations in our study have a very wide range values, all statistical tests on samples were performed on the original data as well as logarithmically transformed data. To evaluate the homogeneity of measured concentrations in different locations, analysis of variance techniques (ANOVA) were used.

\section{Assessment of mist generation homogeneity}

To study the homogeneity of generated mists, 48 clusters of samples were collected, using four closedface cassettes positioned in side-by-side configuration in different locations simultaneously. In order to minimize $\mathrm{Cr}^{6+}$ reduction, samples were collected on PVC membrane filters. ${ }^{24}$

The ANOVA result for 48 clusters of samples showed no statistical significant differences between different locations (P-Value $=0.802$ on original data and PValue $=0.855$ on logarithmic transformed data). It should be noted that, in the above ANOVA model, the effects of other factors including duration of sampling, height of sampling, and distance between samplers were controlled. Figure 4 presents $\mathrm{Cr}^{6+}$ concentration for each

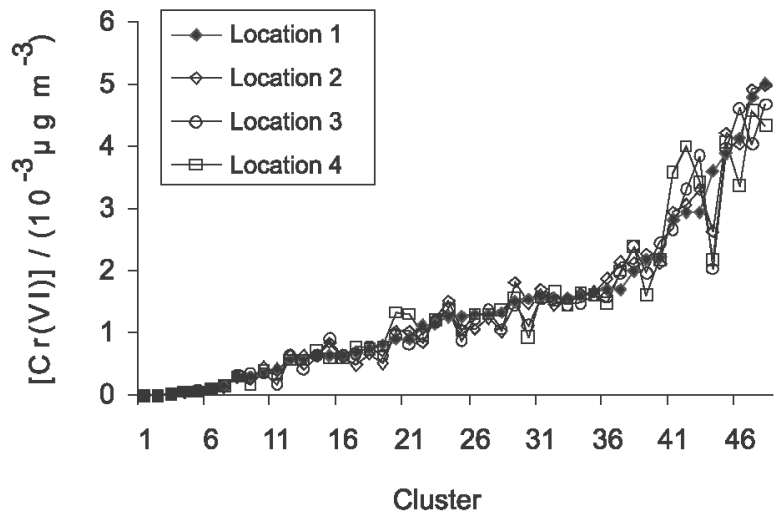

Figure 4. $\mathrm{Cr}^{6+}$ concentrations measured in four locations in 48 simultaneous sample clusters (clusters sorted ascending by $\mathrm{Cr}^{6+}$ concentrations in location 1).

of the 48 clusters, arranged according to one of the studied locations in order of lowest to highest concentrations.

In order to calculate the coefficient of determinations $\left(\mathrm{R}^{2}\right)$ and regression lines among different locations, additional statistical tests were performed. The findings are also depicted in Figure 5. These plots demonstrate the strong agreement of $\mathrm{Cr}^{6+}$ concentration in different locations. Correlations and regression equations were also calculated. The regression line slopes were compared with the slope of unity and their intercept with zero. Statistical results indicated that, neither the intercepts of the lines differ from zero, nor their slops were different from unity (Figure 5). Also, perwise correlation between concentrations among different locations results in a value of $\mathrm{R}^{2}$ at least equal to 0.97 . Hence, a high agreement in $\mathrm{Cr}^{6+}$ concentrations among different locations can be concluded.

\section{Optimum sampling height}

Due to lack of certain recommended sampling height for source samplings, the various heights were used in different studies. ${ }^{11,13,25}$ In this project, for determining the optimum sampling height to obtain the most mist emission uniformity, the samples were collected at different heights

Table 1. Descriptive statistics of $\mathrm{Cr}^{6+}$ concentrations in 183 samples collected in mist generator

\begin{tabular}{ccccccc}
\hline $\begin{array}{c}\text { Sampling } \\
\text { Location }^{\mathrm{a}}\end{array}$ & $\mathrm{N}$ & $\begin{array}{c}\text { Mean concentration } \\
{\left[\mu \mathrm{g} \mathrm{m}^{-3}\right]}\end{array}$ & $\begin{array}{c}\text { Median } \\
{\left[\mu \mathrm{g} \mathrm{m}^{-3}\right]}\end{array}$ & $\begin{array}{c}\mathrm{SD} \\
{\left[\mu \mathrm{g} \mathrm{m}^{-3}\right]}\end{array}$ & $\begin{array}{c}\text { Minimum } \\
{\left[\mu \mathrm{g} \mathrm{m}^{-3}\right]}\end{array}$ & $\begin{array}{c}\text { Maximum } \\
{\left[\mu \mathrm{g} \mathrm{m}^{-3}\right]}\end{array}$ \\
\hline 1 & 48 & 1430.8 & 1263 & 1251.4 & 5.7 & 5000 \\
2 & 47 & 1376 & 1051 & 1225.2 & 5.2 & 4980 \\
3 & 48 & 1386.1 & 1090 & 1239.1 & 4.3 & 4680 \\
4 & 40 & 1523.9 & 1352 & 1171.2 & 5.2 & 4330 \\
\hline
\end{tabular}

a 60 sampling locations were produced on the sampling chamber in 3 rows (20 sampling location in each row). Locations 1, 2, 3, and 4 were chosen randomly. 

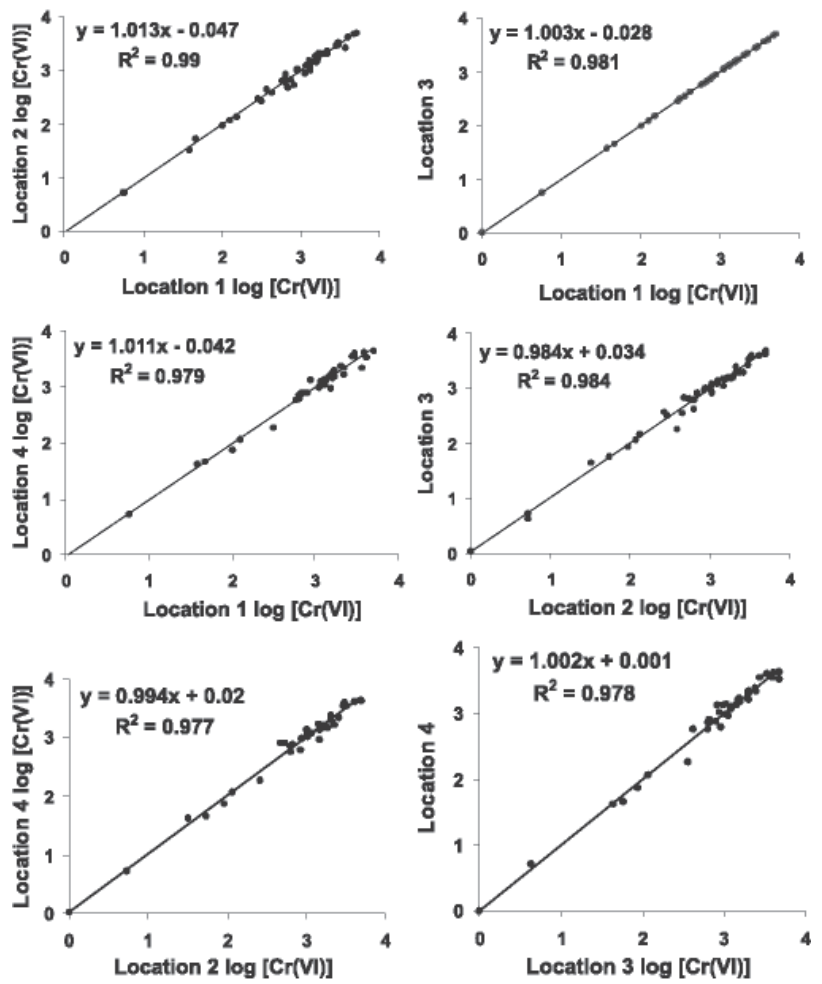

Figure 5. Pair wise $\mathrm{Cr}^{6+}$ concentrations linear agreements at four locations in 48 simultaneous samples clusters.

from the solution surface i.e. 35,50 , and $65 \mathrm{~cm}$ above the electrolyte.

The ANOVA results showed that, there were no statistical significant differences between various locations in each sampling height $(\mathrm{P}-$ Value $=0.86)$. However, the mean and standard deviation of coefficient of variations $(\mathrm{CVs})$ for clusters were $2.2 \pm 2.12,1.89 \pm 1.04$, and 1.89 \pm 1.60 at the heights of 35,50 , and $65 \mathrm{~cm}$, respectively. These results show less variability of measured concentration at height of $50 \mathrm{~cm}$ compared to the other heights (Figure 6).

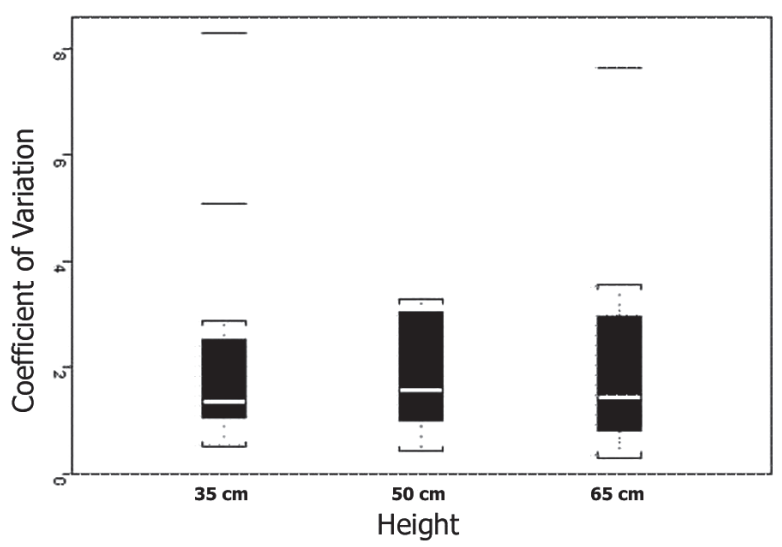

Figure 6. Box plot of CVs of $\mathrm{Cr}^{6+}$ concentrations in 48 simultaneous samples clusters with different height of sampling.
Optimum distance between sampling heads

An actual sample of air should be representative of the atmospheric conditions at the monitoring site at the time of sampling. ${ }^{26}$ It seems that, the distance between samplers is a very important factor, influencing on the $\mathrm{Cr}^{6+}$ determination in side-by-side sampling. Too long distance between samplers may result in non similar data because of non uniformity of measuring parameters, while, too close samplers may produce negative error by affecting on sampling velocity, "starvation effect" ${ }^{27}$ Therefore, the effect of samplers distances were examined in two different situations, i.e., (i) distance between samplers $<7.5$ $\mathrm{cm}$ and (ii) distance between samplers $7.5-15 \mathrm{~cm}$.

Based on ANOVA results, no statistical significant difference was seen between two above mentioned distances $(\mathrm{P}-$ Value $=0.86)$. However, the mean value and standard deviation of coefficient of variations $(\mathrm{CVs})$ for clusters in above distances were $1.65 \pm 0.92$, and $2.07 \pm$ 1.77 , in that order. This shows less variability of measured concentrations at the distance of $<7.5 \mathrm{~cm}$ compared to another distance $(7.5-15 \mathrm{~cm})$ (Figure 7).

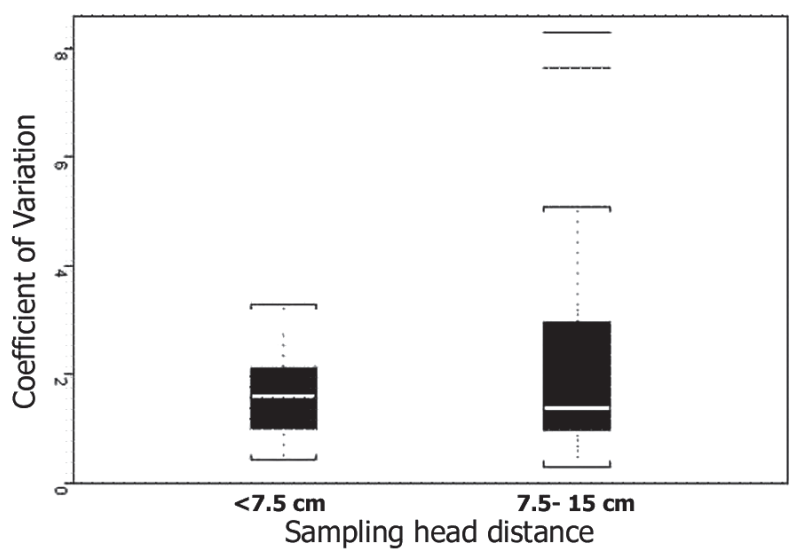

Figure 7. Box plot of CVs of $\mathrm{Cr}^{6+}$ concentrations in 48 simultaneous samples clusters with different sampling head distance.

\section{Conclusions}

In this project, besides of construction of a mist generator with homogenous chromium concentration, maximum homogeneity of chromium mist was obtained in: (i) Sampling at $50 \mathrm{~cm}$ above the solution surface and (ii) distance between samplers lass than $7.5 \mathrm{~cm}$, in sideby-side samplings.

\section{Acknowledgments}

Special thanks are owed to the School of Public Health and Institute of Public Health Research, Tehran University 
of Medical Sciences, Iran for funding this research and for kindly assistance to conducting this study.

The authors also thank Mr. Solyman Khvvaji and Mr. Ali Kafaei for their valuable technical assistance. The authors are grateful to Dr. M.B. Rokni for revising the present manuscript.

\section{References}

1. Barceloux, D. G.; Clinical Toxicology, 1999, 37, 173.

2. Soraham, T.; Harrington, J. M.; Occup. Environ. Med. 2000, 57,385 .

3. Mancuso, T. F.; Am. J. Ind. Med. 1997, 31, 129.

4. Kiilunen, M.; Ann. Occup. Hyg. 1994, 38, 171.

5. Kuo, H. W.; Lai, T. I.; Int. Arch. Occup. Environ. Health 1997, $70,272$.

6. Gibb, H. J.; Lees, P. S. J.; Pinsky, P. F.; Rooney, B. C.; Am. J. Ind. Med. 2000, 38, 127.

7. Liu, C. S.; Kuo, H. W.; Lai, J. S.; Lin, T. I.; Int. Arch. Occup. Environ. Health 1998, 71, 348.

8. Pope, A. M.; Rall, D. P.; Environmental Medicine: Integrating a Missing into Medical Education, National Academic Sciences: USA, 2000.

9. Bright, P.; Burge, P. S.; O’Hickey, S. P.; Gannon, P. F. G.; Robertson, A. S., Boran, A. Thorax, 1997, 52, 28.

10. UK Health and Safety Executive (HSE), Chromium and You. HSE, 2001. http://www.hse.gov.uk/pubns/indg346.pdf, accessed in April 2005

11. UK Health and Safety Executive (HSE); Method for the Determination of Hazardous Substances, Hexavalent Chromium in Chromium Plating Mists -Colorimetric Field Method Using 1, 5-Diphenylcarbazide, (MDHS 52/3), HSE books: Sudbury, 1998.

12. US Occupational Safety and Health (OSHA); OSHA Analytical Methods Manual, Method ID-215, Hexavalent Chromium in Workplace Atmospheres, OSHA: Salt Lake City, 1998.
13. US National Institute of Occupational safety and Health (NIOSH); NIOSH Manual of Analytical Methods, Method No. 7600, Chromium, Hexavalent, NIOSH: Cincinnati, 1994.

14. US National Institute of Occupational safety and Health (NIOSH); NIOSH Manual of Analytical Methods, Method No. 7605, Chromium, Hexavalent by Ion Chromatography, NIOSH: Cincinnati, 2003.

15. US National Institute of Occupational safety and Health (NIOSH); NIOSH Manual of Analytical Methods, Method No. 7703, Chromium, Hexavalent by Field-Portable Spectrophotometry, NIOSH: Cincinnati, 2003.

16. US Occupational Safety and Health (OSHA); OSHA Proposes Revised Rule on Hexavalent Chromium. http://www.osha.gov/, accessed in July 2005.

17. Ashley, K.; Howe, A.; Demang, M.; Nygren, O.; J. Environ. Monit. 1997, 5, 707.

18. Zodrow, G. G.; Article Archive, http://www.pfonline.com accessed in July, 2005.

19. Kuo, Y. W.; Wang, C. S.; AIHA J. 2002, 63, 5.

20. Kuo, Y. W.; Wang, C. S.; J. Aerosol. Sci. 1999, 30, 1171.

21. Kuo, Y. W.; Wang, C. S.; Aerosol Sci. Technol. 1999, 31, 275.

22. Kuo, H. W.; Lai, J. S.; Lin, T. I.; American Industrial Hygiene Association Journal 1997, 58, 29.

23. Kuo, Y. W.; Wang, C. S.; J. Aerosol. Sci. 2002, 33, 297.

24. Abell, M. T. ;Carlberg, J. R.; American Industrial Hygiene Association Journal 1974, April, 229.

25. Boiano, J. M.; Wallace, M. E.; Sieber, W. K.; Gruff, J. H.; Wang, J.; Ashley, K.; J. Environ. Monit. 2000, 2, 329.

26. Ness, S. A.; Air Monitoring for Toxic Exposures: An Integrated Approach, Van Nostrand Reinhold: New York, 1991.

27. Cruz, L.P.C.; Campos, V.P.; Novaes, J.A.P.; Tavares, T.M.; J. Braz. Chem. Soc. 2005, 16, 50.

Received: May 16, 2005

Published on the web: February 17, 2006 